\title{
COMBINATION OF CHEMICAL AND BIOLOGICAL METHODS FOR EFFECTIVE PLANT PROTECTION
}

\author{
DÁVID VOZIK ${ }^{1}$ AND KATALIN BÉLAFI-BAKÓ*1 \\ ${ }^{1}$ Research Institute on Bioengineering, Membrane Technology and Energetics, University of Pannonia, \\ Egyetem u. 10, Veszprém, 8200, HUNGARY
}

\begin{abstract}
The application of combined biological and chemical techniques to control undesirable processes in plant cultivation is becoming ever more important to maintain sustainable and environmentally friendly agricultural systems. Entomopathogenic nematodes and bacteria can provide an effective and special technology in the field of plant protection.
\end{abstract}

Keywords: antimicrobial, entomopathogenic nematodes, bacteria

\section{Introduction}

Nowadays, one of the most important challenges worldwide is the sufficient cultivation of edible plants and crops due to the rising trend in population growth and food demand. Moreover, it is important to solve this problem by implementing sustainable agriculture which prefers natural protection and tries to minimize the intervention of radical chemicals. It was confirmed recently that some synthetic pesticides are environmental hazards. Since the biological degradation of certain pesticides is slow, their bioaccumulation might cause significant damage to ecosystems, soil, natural waters, etc. Therefore, the idea of protecting crops has been extended and a new concept, "Integrated Pest Management" (IPM), introduced which involves chemical, biological and biotechnological methods together with modern cropping, cultivation and breeding technologies [1] in a way which minimizes any risk of environmental damage.

To apply this concept in practice requires comprehensive knowledge of the crops, fitopathogenic microorganisms as well as their enemies, and the behaviour of chemicals (e.g. pesticides) that may be used. A field that has hardly been researched are the so-called entomopathogenic nematodes and bacteria which have been studied in Hungary for a significant period of time [2].

\section{Entomopathogenic nematodes and bacteria}

Entomopathogenic nematodes are a group of thread worms that kill certain insects. They enter - in the form of infective juveniles - into the insects, live as parasites

\footnotetext{
*Correspondence: bako@almos.uni-pannon.hu
}

inside them and cause host mortality within 1-2 days. It has turned out, however, that this is not only caused by the nematodes themselves but certain bacteria play an important role as well.

Entomopathogenic bacteria live in symbiosis with entomopathogenic nematodes $[3,4]$. The nematodes provide shelter for the bacteria, an area of the interior part of the intestine of the infective juveniles is transformed into a bacterial chamber where cells of symbiotic bacteria are located. The relationship is highly specific: e.g. the nematodes of Steinernema usually carry species of Xenorhabdus bacteria, while Heterorhabditis carry Photorhabdus bacteria.

When entering an insect, infective juveniles release the bacteria, which start multiplying rapidly in the haemolymph. It has been proven that although the bacteria are primarily responsible for the mortality of the insect host, the nematodes also produce a toxin which is lethal to the insect. These nematode-bacteria complexes can be applied successfully as biological control agents against insect pests in agriculture [5]. Some of these agents are available commercially, as listed in Table 1, where the target insects, habitats and places of usage are presented [6-8].

\section{Antimicrobial compounds}

Entomopathogenic bacteria contribute not only to the successful activity of entomopathogenic nematodes but can produce special compounds with an antimicrobial effect as well. The main purpose of producing these compounds is to protect the colonized cadaver in the soil [9]. The antimicrobial compounds of entomopathogenic bacteria have been tested and it would seem that these natural agents show a wide range of bioactivities of medical and 
Table 1: Examples of the successful application of nematode-bacteria complexes [6-8]

\begin{tabular}{cccc}
\hline & Target & Habitat & Where \\
\hline Japanese beetle & Popillia japonica & subterranean & lawn, turf \\
black vine weevil & Otiorhynchus sulcatus & subterranean & strawberry plants \\
fungus gnats & Lycoriella species, Bradysia species & subterranean & mushroom production \\
diaprepes root weevil & Diaprepes abbreviatus & epigeal & citrus \\
invasive mole cricket & Scapteriscus vicinus & epigeal & lawn, turf \\
codling moth & Cydia pomonella & cryptic & apple, pome fruit \\
\hline
\end{tabular}

Table 2: Plant pathogens tested

\begin{tabular}{lll}
\hline Pathogen & Effect & Ref. \\
\hline Phytophthora nicotianae & root rot disease of tobacco & {$[13]$} \\
Erwinia amylovora & fire blight disease of several plants that belong to Rosaceae, e.g. apple, pear, etc. & {$[14]$} \\
Ralstonia solanacearum & brown rot disease of potato & {$[15]$} \\
\hline
\end{tabular}

agricultural interest, e.g. antibiotic, antimycotic and insecticidal effects $[10,11]$. For analytical purposes, Fourier Transform Infrared spectrometry (FTIR) was used to identify these compounds [12].

In our laboratories, secondary metabolites of Xenorhabdus budapestiensis (isolated in Hungary) have been investigated [13]. The bacterium was maintained on a Luria Agar (LA) medium and freshly subcultured. The cells were cultured in $1000 \mathrm{~mL}$ flasks and incubated on a gyrorotary shaker at $25^{\circ} \mathrm{C}$. Then the cells were removed by centrifugation and the supernatant extracted. The cell-free filtrate was further purified by chemical methods (adsorption and filtration) to obtain a peptide-rich fraction. This fraction was applied to test for various plant pathogens, as listed in Table 2, including pathogens of tobacco, apple and potato (the latter of which is widespread in Hungary, causing serious damage to inland agriculture).

The investigations involved in vitro bioassays, where the antibacterial activity of the biofraction was determined on solid media. In an agar diffusion test, the tested bacterium was mixed with soft agar poured onto LA plates, then a small hole was made in the centre and the biopreparation of the filtrate added [13]. For the so-called overlay test [13], the antimicrobial preparation was incubated on the solid Luria Broth Agar (LA) plate then the pathogenic microorganism in soft agar was spread onto the surface. In both cases, an inhibition zone can be identified and determined, if the biopreparation was effective against the pathogenic strain. An example of the agar diffusion bioassay is given in Fig. 1. A picture taken from a successful overlay bioassay test is shown in Fig. 2. In our laboratory, in vitro bioassays proved that the biopreparations containing the antimicrobial compounds could be successfully used against these pathogens.

Moreover, in planta (in field trials), a bioassay was conducted using infected apple blossom (Erwinia amylovora) which was treated with the biopreparation. It was concluded to be suitable to reduce the symptoms of the infected plants, thus it can be considered as a promis-

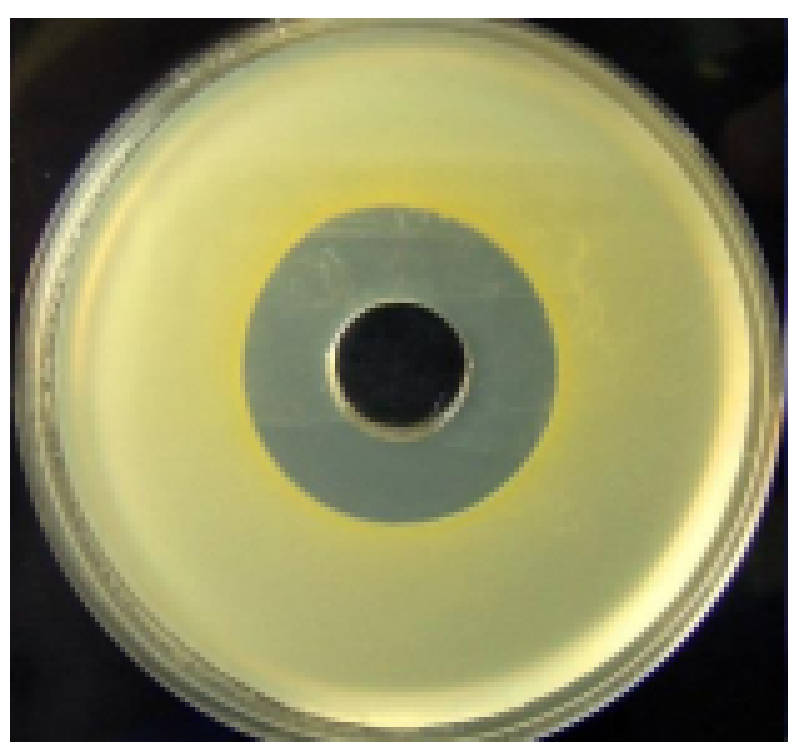

Figure 1: Antibacterial effect of the preparation in the agar diffusion test.

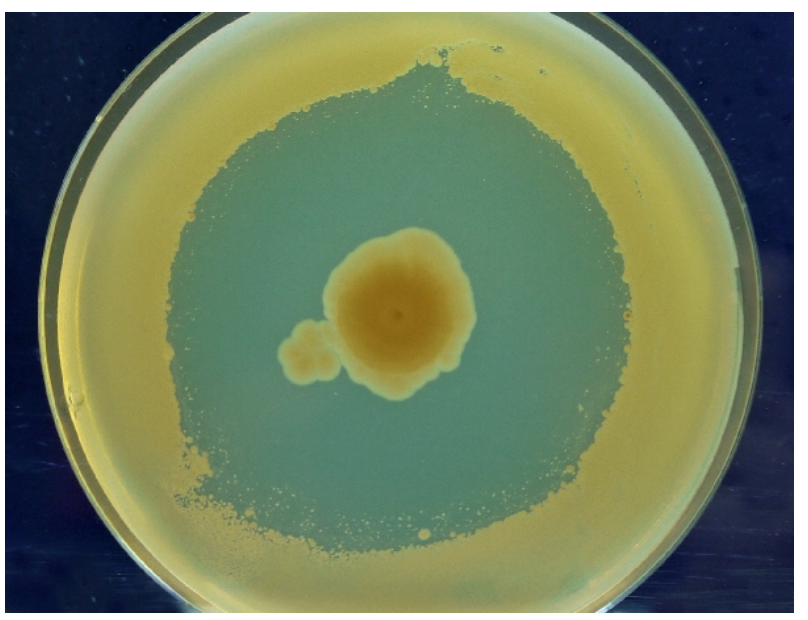

Figure 2: The antagonistic effect of $X$. budapestensis against E. amylovora EA1 bacteria in an overlay test. 


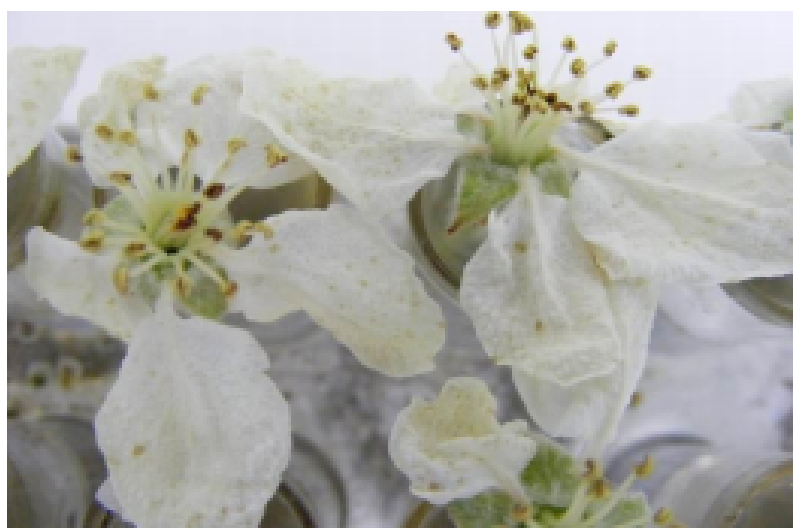

Figure 3: Infected apple blossom treated with the biopreparation.

ing biological agent $[14,15]$. This successful treatment is illustrated in Fig. 3.

Other than plant pathogens, the peptide-rich fraction of Xenorhabdus budapestiensis has recently been tested against species of fungi in vitro [16] in clinical samples. Candida albicans, Candida lusitaniae, Candida krusei, Candida kefyr, Candida tropicalis and Candida glabrata were used in the research by applying the agar diffusion method. The results proved that every Candida species is sensitive to the preparation, thus it would seem that the fraction has a fungicide impact as well.

\section{Conclusion}

In summary, the symbiotic complex of entomopathogenic nematodes and bacteria can be considered as efficient biological agents to control some insect pests, but the secondary metabolites of the bacteria can be effectively used against other pathogenic bacteria and fungi. As a result, their applications can contribute significantly to successful plant protection by providing numerous environmental benefits and can be considered as an important component of "Integrated Pest Management" (IPM).

\section{REFERENCES}

[1] Act XXXV on plant protection (2000, Hungary) http://www.kvvm.hu/szakmai/hulladekgazd/jogszabalyok/2000 _XXXV_tv.htm

[2] Lengyel, K.; Lang, E.; Fodor, A.; Szállás, E.; Schumann, P.; Stackebrandt, E.: Description of four novel species of Xenorhabdus, family Enterobacteriaceae: Xenorhabdus budapestensis sp. Nov., Xenorhabdus ehlersii sp. nov., Xenorhabdus innexi sp. nov., and Xenorhabdus szentirmaii sp. nov., Syst. Appl. Microbiol. 2005, 28(2), 115-122 DOI: 10.1016/j.syapm.2004.10.004

[3] Boemare, N. E.; Akhurst, R. J.; Mourant, R. G.: DNA relatedness between Xenorhabdus spp. (Enterobacteriaceae), symbiotic bacteria of entomopathogenic nematodes, and a Proposal to trans- fer Xenorhabdus luminescens to a new genus, Photorhabdus gen. nov., Int. J. Syst. Bacteriol. 1993, 43(2), 249-255 DOI: 10.1099/00207713-43-2-249

[4] Thomas, G. M.; Poinar, G. O.: Xenorhabdus gen. nov., a genus of entomrnopathogenic, nematophilic bacteria of the family Enterobacteriaceae, Int. J. Syst. Bacteriol. 1979, 29(4), 352-360 DOI: 10.1099/00207713-29-4-352

[5] Smart, G. C.: Entomopathogenic nematodes for the biological control of insects, J. Nematology 1995, 27(4S), 529-553 https://www.ncbi.nlm.nih.gov/pmc/articles/PMC2619649/pdf/ 529.pdf

[6] Koppenhöfer, A. M.: Nematodes, in Lacey, L.A.; Kaya, H.K. (Eds.): Field manual of techniques in invertebrate pathology. Application and evaluation of pathogens for control of insects and other invertebrate pests (Springer, Dordrecht, The Netherlands) 2007, ISBN: 978-1-4020-5933-9

[7] Georgis, R.; Koppenhöfer, A. M.; Lacey, L. A.; Bélair, G.; Duncan, L. W.; Grewal, P. S.; Samish, M.; Tan, L.; Torr, P.; van Tol, R. W. H. M.: Successes and failures in the use of parasitic nematodes for pest control, Biol. Control 2006, 38(1), 103-123 DOI: 10.1016/j.biocontrol.2005.11.005

[8] Lacey, L. A.; Georgis, R.: Entomopathogenic nematodes for control of insect pests above and below ground with comments on commercial production, J. Nematology 2012, 44(2), 218-225 https://www.ncbi.nlm.nih.gov/pmc/articles/PMC3578470/pdf/ 218.pdf

[9] Akhurst, R. J.: Antibiotic activity of Xenorhabdus ssp., bacteria symbiotically associated with insect pathogenic nematodes of the families Heterorhabditidae and Steinernematidae, J. Gen. Microbiol. 1982, 128(12), 3061-3065 DOI: 10.1099/00221287-12812-3061

[10] McInerney, B. V.; Gregson, R. P.; Lacey, M. J.; Akhurst, R. J.; Lyons, G. R.; Rhodes, S. H.; Smith, D. R.; Engelhardt, L. M.; White, A. H.: Biologically active metabolites from Xenorhabdus spp., Part 1. Dithiolopyrrolone derivatives with antibiotic activity, J. Nat. Prod. 1991, 54(3), 774-784 DOI: 10.1021/np50075a005

[11] Webster, J. M.; Chen, G.; Hun, K.; Li, J.: Bacterial metabolites, In: Gaugler, R. (Ed.) Entomopathogenic Nematology (CABI Publishing, New York, USA) 2002, 145-168 ISBN: 08-5199-567-5

[12] Vozik, D.; Madarász, J.; Csanádi, Zs.; Fodor, A.; Dublecz, K.; Bélafi-Bakó, K.: Study on analysis of antibiotic compounds from entomopathogenic bacteria by FT-IR, Hung. J. Ind. Chem. 2012, 40(2), 83-86 https://mk.unipannon.hu/hjic/index.php/hjic/article/download/346/316

[13] Böszörményi, E.; Érsek, T.; Fodor, A.; Földes, L. Sz.; Hevesi, M.; Hogan, J. S.; Katona, Z.; Klein, M. G.; Kormány, A.; Pekár, Sz.; Szentirmai, A.; Sztaricskai, F.; Taylor, R. A. J.: Isolation and activity of 
Xenorhabdus antimicrobial compounds against the plant pathogens Erwinia amylovora and Phytophtora nicotianae, J. Appl. Microbiol. 2009, 107(3), 746-759 DOI: 10.1111/j.1365-2672.2009.04249.x

[14] Vozik, D.; Bélafi-Bakó, K.; Hevesi, M.; Böszörményi, E.; Fodor, A.: Effectiveness of a peptiderich fraction from Xenorhabdus budapestensis culture against fire blight disease on apple blossoms, Not. Bot. Horti Agrobot. Cluj-Napoca 2015, 43(2), 547-553 DOI: 10.15835/nbha4329997

[15] Vozik, D.; Bélafi-Bakó, K.; Hevesi, M.; Böszörményi, E.; Polgár, Zs.; Fodor, A.: Effectiveness of antimicrobial compounds produced by entomopathogenic nematode symbiotic bacteria to control pests and bacterial plant diseases, International Organization For Biological Control - West Palaearctic Regional Section Bulletin 2016, 113 17-21 ISBN: 978-92-9067-296-8

[16] Burgetti-Böszörményi, E.; Németh, S.; BélafiBakó, K.; Vozik, D.; Barcs, I.; Csima, Z.: The antifungal effect of Xenorhabdus budapestiensis bacteria biopreparatum on some Candida species in vitro, Dev. Health Sci. 2018, 1(7), 57-62 DOI: 10.1556/2066.2.2018.17 